\title{
MPs accuse health officials of unconcern over risks and benefits of DNA research
}

BRITISH members of Parliament last week accused officials of the Department of Health and Social Security of displaying an "active disinterest" (sic) in the possible health risks of research involving the use of recombinant DNA techniques.

In particular, the MPs expressed concern that a non-specialist assessor who sits on the Genetic Manipulation Advisory Group on behalf of the DHSS should represent the UK on an ad hoc group of experts which has drawn up a draft directive on the regulation of genetic manipulation experiments for the European Economic Commission.

These concerns were voiced at a meeting last week of a subcommittee of the House of Common Select Committee on Science and Technology which is currently holding a series of public meetings on genetic engineering in the UK.

Mr C. M. Regan, under-secretary responsible for public and environmental health at the DHSS, told the MPs that because recombinant DNA techniques essentially involved research processes, their safety was a matter for the Department of Education and Science and the Health and Safety Executive rather than DHSS. Although

\section{Forest destruction must be halted, says report}

ThE Earth's forests are now decreasing in size annually by at least 11 million hectares - the area of Bulgaria according to the latest Worldwatch report. It warns that man's destruction of tropical forests "is taking an enormous economic and environmental toll".

The study's author, Erik Eckholm, points out that the "fundamental importance of forests to human wellbeing" is generally ignored by those who analyse the basic needs of the world's poor to reduce the forest deprivation now suffered by many". (The Worldwatch Institute is doing its best to cure the blindness: the very first Worldwatch paper was Eckholm's 'The Other Energy Crisis: Firewond'.)

Information about the extent and condition of the world's forests is remarkably scanty, government statistics are frequently inaccurate and "sometimes doctored outright", the report says. But Eckholm estimates that approximately $20 \%$ of the Earth's land is now covered by dense forest-that is
DHSS had an assessor on GMAG, the public health aspects of possible hazards was therefore "not a matter which falls to us directly".

The MPs accused the DHSS officials of taking an unimaginative approach, both to their responsibilities for protecting the public from unpredictable hazards of the research, and to the possibilities that the research promised for the production of drugs such as insulin.

$\mathrm{Mr}$ Ted Leadbitter, who had last week accused DES officials of using "under-secretary language" in giving evasive replies to the members' questions, referred to the memorandum submitted to the subcommittee by the DHSS as a "pathetic document" revealing what he called an "active disinterest" in the matters under review.

$\mathrm{Mr}$ Leadbitter's wrath descended in particular on Dr T. J. B. Geffen, a senior principal medical officer at DHSS who represents the department on GMAG, but who told the committee that he has no particular experience or training in the techniques being discussed, and that his role was essentially that of providing a channel of communication between the department and GMAG.

Dr. Geffen, who was a hospital

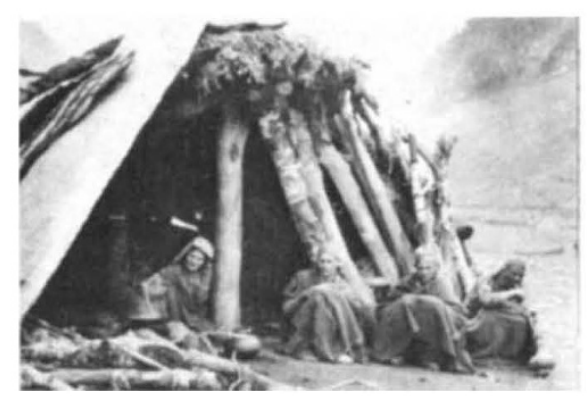

about half of the area that would be forested in the absence of man. Another 10\% of land is "open woodland".

The forest area of North America and Europe is roughly stable. Almost all the loss is occurring in the humid tropical forests of Latin America, Asia and Africa. where Eckholm says the crude deforestation figures greatly underestimate the damage because "they reflect neither the massive degradation of timber and other biological resources occurring within many still-standing forests nor the severe depletion of open woodland and countryside vegetation that currently blights most third world countries".

The three principal causes of deforestation are, in order of importance. the unplanned spread of agriculture. physician before joining the DHSS, told the MPs that he did not feel this role required any particular expertise, and that he felt there was no need for the DHSS to employ anyone with such experience since advice on technical matters relating to advances in DNA research could be obtained from consultants.

Given Dr Geffen's "relatively small" contribution to GMAG, the MPs therefore wanted to know why he had been chosen to represent the UK on an expert committee which had prepared draft directives on genetic manipulation for the EEC. They were not satisfied with the answer that the word "expert" in such a context meant someone with broad experience in the matter under discussion.

Mr. Arthur Palmer, chairman of the select committee, said that he felt the DHSS was taking a negative approach to the question of both the risks and the benefits of recombinant DNA research, and that the committee would try to put questions to $\mathrm{Mr}$ David Ennals, Secretary of State for Health, "to see if this policy of detachment is the best one".

David Dickson

firewood collection for cooking, and indiscriminate timber harvesting. Tree planting makes up only a small fraction of the loss.

"As a result the real prices of wood and wood products are likely to rise substantially over the coming decades . . .", Eckholm writes. "Meanwhile the continued loss of forests will accentuate the environmental costs of denudation already apparent in many countries-erosion, desertification, siltation, flooding and the extinction of species." And, he adds. deforestation may rival fossil-fuel burning as a source of atmospheric acrbon dioxide.

Although evidence for the economic consequences of deforestation is extremely scarce, Eckholm argues that it has been a major driving force behind the past decade's worldwide inflation. The price of wood has been rising in real terms by $4 \%$ a year during the 1970's. he estimates - and the increases have been most severe in the third world.

"A simple board costs twice as much in Pakistan as in the United States though the income of the average American is 46 times that of the average Pakistani", Eckholm reported. Families in some West African cities spend $\frac{1}{4}$ of their income on firewood. 